ANNA HEDO,

Borys Grinchenko Kyiv University (Kyiv, Ukraine)

e-mail: a.hedo@kubg.edu.ua,ORCID 0000-0003-4151-0747

MARK MILIUTIN,

Borys Grinchenko Kyiv University (Kyiv, Ukraine)

e-mail:mailto:a.hedo@kubg.edu.ua,mymiliutin.iff19@kubg.edu.ua,ORCID 0000-0002-2676-9139

\title{
EPIDEMICS IN KYIV COVERED IN THE NEWSPAPER PERIODICALS OF THE CITY OF THE LATE 19th - EARLY 20th CENTURIES
}

\begin{abstract}
The article examines the coverage of the sanitary and epidemiological situation in the city in the late 19th - early 20th centuries in the Kyiv newspapers "Kievlyanin", "Kievskie Vesti", "Kievskaya Mysl", "Yuzhnaya Kopeyka". The processing of newspaper materials made it possible to identify problematic areas of work of the city authorities in the sanitary and communal spheres, namely inadequate control over observance of health standards in urban markets, failure to solve the problem of natural dumps and homeless people, illegal alcohol sales, lack of timely repair of roads, construction of water supply and sewerage. These factors were the main causes of epidemics of typhus, measles, tuberculosis, smallpox, cholera. Analysis of statistics on the pages of periodicals allows tracing the number of people affected by epidemics, identifying typical diseases for each district of the city, caused by their geographical location, population, location of facilities such as prisons, bazaars, cemeteries, hospitals.
\end{abstract}

Key words: newspapers, Kyiv, epidemics, diseases, hospitals, health care.

\section{Introduction}

Epidemiological welfare of cities has traditionally played an important role in community life and the management process of city mayors. Today, when the problems of the epidemiological situation of cities are relevant due to the coronavirus pandemic, the study of historical experience of the population during the pandemics is of particular importance, and the study of communication in times of epidemic crises has new urgency. The works by A. Volobueva "Formation and development of the Kyiv press (1835-1917)" (2008), G. Senkevich "City newspaper: creative social paradigm of the functioning" (2010), O. Levchuk "Press of Kyiv in 1905-1914: features of typologization" (2016) are dedicated to the history of development and source studies in the context of studying Kyiv periodical sources in the late 19th - ealy 20th centuries.

In the field of study of Kyiv everyday life, it is worth noting the scientific achievements of $O$. Vilshanska (1995), A. Makarova (2000), O. Levchuk (2017), O. Musiyachenko (2016).

The analysis of newspaper periodicals as a key communication space of the 19th - early 20 th century allows tracing the attitudes prevailing among the general public during the plagues and the reaction of government officials to the challenges they faced.

Given the role of the media in shaping public opinion, as well as its reflection, the analysis of media space allows forming a holistic view of public mood, the state of the population, measures taken by local authorities and their perception by the public.

Just like today, the analysis of newspaper columns shows that the topic of epidemic well-being played a key role in the public discourse of the late 19th - early 20th centuries. And if today we observe that a significant segment of the media is devoted to this topic, its coverage does not leave the main pages of leading tabloids, is actively discussed on TV, has become a leading topic covered in the so-called "New Media", and even more, is introduced in separate columns on the official resources of state institutions, international organizations, embassies and consulates - the opportunities of the media space of the 19th -early 20th century were fixated mainly in the newspaper segment, which was the main and most popular form of media.

Materials of urban periodicals of the late 19th - early 20th centuries allow reconstructing the sanitary and epidemiological situation in Kyiv. These are the newspapers "Kievlyanin", "Yuzhnaya Kopeyka", "Kievskie Vesti", "Kievskaya Mysl". Careful analysis of the media space, which at that time was represented by the newspaper segment, allows recreating a vivid picture of the life of the citizens of that time almost hour-by-hour. Newspaper pages allow the researcher to trace the system of medical, pharmacy and medical-recreational facilities designed to meet the needs and requests of citizens in health care, identify the main problems of medicine in Kyiv at the time, ways to solve them etc.

The Kyiv press confirms the information on local lore literature and archival materials that the district health inspectorate, which consisted of various specialized structures, including the City Department of Public Health, organized health care in Kyiv. According to Kyiv newspaper periodicals, in the provincial center during 1905-1914, there were city hospitals on the balance of the Kyiv ad- 
ministration, medical institutions created at public expense and with the assistance of famous patrons, clinics at monasteries, specialized centers of the Medical Faculty of Kyiv University, the Ambulance Society, which began operating in the city in the late 19th century, as well as a number of private hospitals and medical offices, information about which is provided by pages of newspapers (Levchuk, 2018: 189-190).

A characteristic feature of newspapers as an information carrier is their ability to contain publications that may be used as a separate historical source to study different aspects of the same problem. Thus, forming a single system of one issue of the newspaper, chronicles, notes, reports, analytical articles, advertising and literary texts reflect different aspects of urban life, have their own form of presenting information.

The purpose of this study is to clarify the source value of information from Kyiv newspaper periodicals of the late 19th - early 20th century for research on the sanitary and epidemiological situation in the city.

\section{Research Methods}

Qualitative and quantitative analysis - content analysis, which is a formalized method of interpreting texts, allows increasing the informativeness of such an inexhaustible source as the press. Its essence is to identify the features, traits, properties of the source, which would reflect the essential aspects of its content. In this case, the qualitative characteristics of the texts become measurable, suitable for accurate computational operations, and the results of the analysis become more objective. At the end of the 19th century, it was noted that the propaganda tasks of the press, commercial purposes of information production were aimed at spreading and replicating a range of ideas, values, patterns of behavior, the description of which in the press quickly became stereotypic, overgrown with characteristic stable stamps and clichés. In this regard, fragments of content, which can be easily identified due to the repetition, circulate though the flow of newspaper information, record and measure the frequency of their use, which is the idea of content analysis.

Thus, the use of qualitative and quantitative analysis in the context of this study has been useful for the study of advertising and reference sections of newspapers, which are determined by the consistency and relative homogeneity of the content to detect the frequency of indication. The sections "Internal News", "Mixtures" often raised issues of health care (the state of local markets, prisons, sewerage, spread of rodents) and the municipal system (transport, water supply, sewerage, natural dumps). The analysis of announcements, advertisements and the rubric "Doctors and Hospitals" allows finding out typical diseases of Kyivans, the state of hospitals (including private ones), observance of epidemic rules. Content analysis of medical advertising shows that dentists, obstetricians and "secret medicine doctors" (venereologists) most often offered their services.

\section{Results and Discussion}

Since the 1970s, the population of Kyiv had been growing rapidly. This is evidenced by quantitative indicators: in 1874, the city had 124 thousand inhabitants, in $1897-248$ thousand, and in $1913-600-700$ thousand inhabitants (Vilshanska, 2011). Since the 1970s, the population of Kyiv had been growing rapidly. This is evidenced by quantitative indicators: in 1874 , the city had 124 thousand inhabitants, in $1897-248$ thousand, and in $1913-600-700$ thousand inhabitants ${ }^{1}$.

The analysis of the newspaper "Kievlyanin" shows that the sanitary and epidemic situation of the urban environment of the late 19th - early 20th century was in a deplorable state. Typical diseases for the people of Kyiv at that time were typhoid, tuberculosis, various venereal diseases, and cholera. Among the problems in the field of sanitation are unsanitary conditions, epidemics, environmental imbalances, and disorder in the city's health care system.

\section{Пожертвованія въ пользу тифознихъ больныхъ. Ввовь поступило въ редавціко скіевлянша по потевовашія: оть Г-жи Ко- анговскоі 5 руб. П Н. Н. Завадсво й иаз Баву 5 _., a всего cъ прежини 191 p.}

Donation in favor of typhoid patients. Once again, the "Kievlyanin" editorial office received a donation: from Mrs. Kolikovskaya 5 rubles and N. N. Zavadskaya from Baku 5 rubles, and with the previous 191 rubles

\section{Donation in favor of typhoid patients. Kievlyanin, 1898 № 4}

Highlighting this aspect, it is necessary to identify several factors that led to this situation.

Firstly, it is worth noting the state of Kyiv's bazaars, namely the Sinnyi, Galician, Jewish bazaars.

Firstly, it is worth noting the state of Kyiv's bazaars, namely the Sinnyi, Galician, Jewish.

Thirdly, the health of Kyivans was negatively affected by the poor sewerage and water supply system, that did not meet the needs of the time.

The functioning of Kyiv markets was unregulated, and the lack of strict control over the observance of sanitary norms by the city authorities turned the places of trade into natural dumps, that were distributors of diseases and dirt.

The journal "Kievskaya Starina" for 1903 reported that in July 1831, Kyiv military governor B. Knyazhnin demanded the doctors and law enforcement officers to control the "quality of fruit and all products sold in general, strictly supervising that immature, spoiled and rot are not sold", because the governor considered "excessive overeating and carelessness in food" the main reason for the spread of cholera ${ }^{2}$.

On the pages of periodicals, we find confirmation that there was no proper control over the quality of goods in urban markets, sellers offered visitors a life-threatening product. A chronicle entitled "Poisonous Sausages", published in the newspaper "Yuzhnaya Kopeyka" on May 10, 1912, stated "City sanitary doctor V. Voskresensky inspected Konsevich's sausages at the Zhitniy bazaar and found rotten sausages put up for sale that were all cov-

\footnotetext{
${ }^{1}$ Kievlyanin. 1900. № 39.

2 Measures against cholera. 1831. Kievskaya Starina. 1903. Iss.11. P.72-73.
} 
ered with mucus, with horrible smell and made of completely unusable meat. It turned out to be more than a pood of such sausages"3. Despite the fact that the authorities entrusted the control over the observance of sanitary norms to the police and the message stated: "all sausages were destroyed and a report was prepared"4, there were facts of conspiracy between the police and unscrupulous sellers.

To maintain cleanliness in the markets, all traders were taxed on the cleaning of market squares, but in the chronicle of "Kievlyanin" on March 21, 1908, a typical picture of the then Kyiv bazaar was described: "Yesterday we reported on the impossible state of the Sinnyi Bazaar. But it turns out that other market squares are in even more terrible conditions [...] Now that the snow and ice have melted, it all opened up and began to decay [...] Despite this, the city authorities have completely stopped cleaning the area from sewage" ${ }^{\prime 5}$. The correspondent further reported on the consequences of such a careless attitude of the authorities: "in most markets, card gambling and crap shooting flourish and the peasants are robbed by all sorts of dark personalities ... a real disaster for the townspeople is a whole army of beggars and all sorts of others who pour out into all the busy streets and corners of the city and aggressively cling to passers-by. Many of these beggars are always drunk and behave extremely defiantly, the police do not take any measures to combat this rioters' and hooligans' invasion of the city, as if it did not concern them",

Speaking of markets as places of concentration of marginalized strata of society, it is necessary to say something about such a phenomenon as prostitution. When reviewing the advertising block of newspapers, a large number of ads by venereologists attracts attention, which may indicate the spread of sexually transmitted diseases, especially syphilis. Confirmation is the column "Doctors and Hospitals" of the daily newspaper "Kievskie Vesti": on November 8, 1907, from 15 ads, 13 offered medical services for the treatment of syphilis, skin and venereal diseases and impotence ${ }^{7}$; on February 7, 1909, all 11 advertisements belonged to venereologists ${ }^{8}$, on March 28, $1909-9$ out of $12^{9}$. Given that this problem affected the personal spheres of life of potential patients, the ads were accompanied by phrases "anonymously" or "confidentially".

The other side of Kyiv's markets was the shadow trade, especially the illegal sale of alcohol intensified after the increase in alcohol prices, as reported by the correspondent of "Gazeta": "ordinary wine $40 \%$ (ppm) by volume will be sold for 8 rubles 40 kopecks per bucket (price was increased by 5\%), alcohol $57 \%$ - 11 rubles 97

\footnotetext{
${ }^{3}$ Poisonous Sausages. Yuzhnaya Kopeyka. 1912. № 498. May 10. P. 3

4 Ibid.

${ }^{5}$ Urban improvement. Kievlyanin. 1908. № 81. March 21. P. 3.

6 Ibid.

Doctors and Hospitals. Kievskie Vesti. 1907. № 146. November 8. P. 1.

${ }^{8}$ Doctors and Hospitals. Kievskie Vesti. 1909. № 37. February 7. P. 4.

${ }^{9}$ Doctors and Hospitals. Kievskie Vesti. 1909. № 84. March 28. P. 1.
}

СХІД Том 2 (3) листопад-грудень 2021 р. kopecks per bucket, alcohol $95 \%$ - 19 rubles 95 kopecks and table wine -12 rubles per bucket"10.

There are evidences in the periodicals about the conditions of detention in Kyiv's prisons, and in the daily newspaper "Yuzhnaya Kopeyka" of May 21, 1912, there is a publication entitled "The Wrong Side of Kyiv. Hellhole" with the following information: "the detainee falls [...] into a hellhole, the whole furniture of which consists of bare bunks and the famous "parasha" - a capacious vessel for the natural needs of detainees [...] No bedding is provided for sleeping, they sleep directly on bare boards, using their own dresses [...] but the worst thing is that at night they are stuck by insects, and especially bedbugs. The arrested are beating, suffocating bedbugs, but this does not make the hordes smaller"11. From the available information, it can be concluded that bedbugs were the result of miserable living conditions of the prisoners, complete unsanitary conditions, where it was not a question of following the simplest rules of hygiene or healthy eating. According to the author of the above article, only those prisoners who had their own money could count on "dry" food.

The living conditions of the prisoners led to the spread of such diseases as diphtheria, smallpox, tuberculosis, and scarlet fever. As a result, on a city scale, prisons posed a significant threat to its well-established existence as a social organism. First, they worsened the health situation within the area where they were located. For example, Lukyanovka, where Lukyanov Prison Castle was based, was a leader in typhoid and tuberculosis at the time. The population living near such facilities faced psychological (a contingent that created trouble disturbing the peace gathered near prisons) and housing (the presence of fleas, rats, cockroaches, bedbugs, etc.) problems. One of the methods of combating with pests were products of the Association "Kyiv Perfume Laboratory"12.

In 1901, plagued rats were seen in the Port of Odessa, so the Kyiv city authorities announced that they would pay 3 kopecks for each rat killed. In November, the newspaper "Kievlyanin" noted that "the corpses of rats should be brought in rags "soaked in kerosene" to the fire department in the morning from 10 to $14 \mathrm{am}^{\text {"13. }}$. Among the preventive measures aimed at preventing the emergence of cholera outbreaks, the city council called on homeowners, representatives of institutions, hotel owners: "1) to immediately take measures to clean the estates from garbage, manure; 2) to inform the local sanitary doctor about each suspicious case of the disease, and especially about persons who came from the southern provinces, and 3) to pay attention to the cellars and especially to the disease and death of rats, to inform the orderlies" $^{14}$.

All these factors influenced the pricing policy of real estate in areas located near punitive institutions. Regardless of the quality of housing, the rental or market value of apartments was one step lower than identical apartments in other parts of the city.

\footnotetext{
${ }^{10}$ According to the order of the Minister of Finances... Gazeta. 1908. № 33. October 10. P.19.

${ }^{11}$ The Wrong Side of Kyiv. "Hellhole". Yuzhnaya Kopeyka. 1912. № 507. May 21. P. 3.

${ }_{12}^{12}$ Anti-bedbug. Yuzhnaya Kopeyka. 1912. № 493. May 5. P. 4

${ }_{13}^{13}$ Kievlyanin 1901 № 309.

Kievlyanin 1901 № 309.
} 
The next aspect in the study of epidemiological problems of the city which deserves attention is the municipal system: transport, water supply, sewerage, natural dumps.

The headlines of the most influential publications in Kyiv at the time, "Kievlyanin", "Kievskie Vesti", "Kievskaya Mysl", and "Poslednye Novosti", were as follows: "Flooding with sewage" ${ }^{15}$, "Lack of water" ${ }^{16}$, "Sewerage affairs"17, "Who poisons drinking water in Kyiv?"18, which recorded numerous facts about the discharge of sewage from the sewerage into the Dnieper, complaints from residents of different areas to the Water Supply Company and the City Railway Company, which, being private incorporated enterprises, were little influenced by the city administration and practically did not fulfill their obligations in the field of public welfare and hygiene, which could not be confronted even by the numerous administrative penalties from shareholders, which often reached 500-600 rubles $^{19}$

With the development of the city's transport system, the question of road repairs arose. Local authorities were unable to respond effectively and in a timely manner, so citizens repaired the street pavement themselves, filling potholes and pits with humus, garbage, "in wet seasons, in addition to the unbearable stench, cholera and other diseases were caused" (Levchuk, 2018).

These facts showed that there was no centralized recycling of waste in the city. In 1911, Dr. Burchak, a doctor at the Kyiv City Council, visited St. Petersburg to study the issue of waste recycling, and got acquainted with the operation of the incinerator. Professor A. Pavlovsky visited the International Hygiene Exposition in Dresden.

According to local newspaper periodicals, one of the most urgent problems of Kyiv's sanitary and epidemiological well-being was the shortage of artesian wells in the city: the water supply system continued to supply Kyiv residents with water from the polluted Dnieper (Levchuk, 2018).

In the 1st issue of "Kievlyanin" for 1898, we find the message "On the water supply of Alexander Hospital"20. It says that due to the expansion of the hospital facilities, the city's water main did not meet the needs of the hospital, because in addition to the hospital, the system is used by nearby bowery. These circumstances could lead to serious consequences in case of a fire, which was especially acute in the summer. To solve this problem, the small hospital council decided to "refer to the city council the issue of increasing the diameter of the water main adjacent to the hospital facilities, and discuss it in conjunction with the introduction of artesian water supply"21.

\footnotetext{
15 Flooding with sewage. Kievskaya Mysl. 1908. № 30 . February 1. P. 5

${ }^{16}$ Lack of water. Kievskie Vesti. 1909. № 133. May 22. P. 4.

17 Sewerage affairs. Kievskoe Slovo. 1905. № 6136. February 1.

P. 2.

${ }^{18}$ Who poisons drinking water in Kyiv. Kievskaya Mysl. 1907

№ 94. April 5. P. 5.

Administrative penalties. Kievskoe Utro. 1910. № 40. September 26. P. 3.

${ }^{20}$ On the water supply of Alexander Hospital. Kievlyanin 1898 № 1

${ }^{21}$ On the water supply of Alexander Hospital. Kievlyanin 1898
} № 1

ISSN 1728-9343 (Print)

ISSN 2411-3093 (Online)

\begin{abstract}
- $\mathrm{K}$ в вопросу о водоснабненіи городской Алеисандровсной больницы. Оь расширепіег помьщевія Ааексапдровской бозьвицы городсвая водопроводая магистраль не удовлетворнеть иуждаяь вь водь городсвой бозьниц. Особенво ато ошущается въ аьтнее врена, есаи пользуются водою ближайшія усадьбы. Вь ато вревя воды въ похарныхъ пранахъ баваеть такъ мало, тго пожарные ругава не могугь вLбрасывать струи воды на крыпу больначшихъ здаяін. 0бстоятельство это мозеть повести вь серьезнымь посаьдетвіямь въ

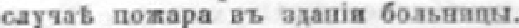

Вь валу 9того въ засьданін малаго большвчнаго совьта, состоявшемси 20 девабря, быао постановаено передать въ городевую управу вопрось объ увеличевіп діаметра водопроводной магистрали, прпаегаьоцеї въ усадьбы больницы, п обеудить его совуtстно $\mathrm{cb}$ вопросогь уетройста артезіапеваго водоснаัตтенія.
\end{abstract}

\section{On the water supply of Alexander Hos- pital}

With the expansion of the premises of the Alexander Hospital, the city water main does not meet the water needs of the city hospital. This is especially felt in the summer, if the nearby estates use the water. At this time, there is so little water in the fire hydrants that the fire hoses cannot throw water jets onto the roof of the hospital knowledge. This circumstance can lead to serious consequences in case of a fire in the hospital building. In view of this, at the meeting of the small hospital council held on December 20, it was decided to transfer the issue of increasing the diameter of the water main adjacent to the hospital facilities to the city council, and discuss it together with the issue of artesian water supply.

\section{On the water supply of Alexander Hospital. Kievlyanin, 1898 № 1}

According to the newspaper "Kievskaya Mysl", as of October 1908, the supply of artesian water reached $1,450,000$ buckets per day and continued to grow steadi$1 \mathrm{l}^{22}$. Already in June 1909, "Kievskie Vesti" recorded $1,940,000$ buckets of water per day, noting that the steady increase in population did not allow stating that the above figures were satisfactory and required an increase in artesian water supply to $2,500,000$ buckets per day ${ }^{23}$. The results of the analysis of three samples of water (artesian, Dnieper unfiltered and filtered), published by Kyiv newspapers, according to the report of the head of the city sanitary station Dr. Raikevych, hardly complied with the norm: "Dnieper water, even the one that passed the filters, turned out to be with water fleas [...] Artesian water is transparent, but its oxidation is significant, which provokes cholera", the newspaper "Kievskaya Mysl" reported in the autumn of $1908^{24}$

\footnotetext{
22 Artesian water supply. Kievskaya Mysl. 1908. № 292. October 21. P. 3.

${ }^{23}$ Meeting on water supply issue. Kievskie Vesti. 1909. № 159. June 17. P. 3.

24 Analysis of water. Kievskaya Mysl. 1908. № 244. September 3. P. 3.
} 
The construction of a modern sewerage system was in great demand for the proper functioning of urban space. Problems and prospects of its construction were reflected in the titles of city periodicals "Expert Sewerage Commission" "25, "On the issue of municipal sewerage"26, "Work to expand the city sewage network" ${ }^{27}$.

Analysis of newspaper materials of the late 19th early 20th centuries allows determining the length and areas of the sewerage system, identifying the main difficulties of its construction, functioning, further expansion and reorganization. Publications of local newspapers testify that despite the efficiency of the Kyiv Sewerage Society, before the revolution of 1905-1906 (during the construction of the first phase), Pechersk, Ploska ${ }^{28}$, Lukyanivska city districts and suburbs were not canalized, but the main activity of the Society concentrated in the socalled "upper city" (Levchuk, 2018).

During the construction of the sewerage system, the Kyiv Canalization Society, which was responsible for the construction, repeatedly violated sanitary norms, as evidenced by the note "Flooding with sewage" in the newspaper "Kievskaya Mysl" on February 1, 1908, as follows: "Sewage sludge overflowed sewage farms and then in large numbers penetrated Vasily Kun's estate and began to flood other estates [...]. At the request of the residents, the police drew up a report to bring the sewerage company to justice"29. In March 1908, the Kyiv Sewerage Society was liquidated and the sewerage system was transferred to the city administration, this event that was well received by the public.

In the same year, a project was developed to sewer all districts of Kyiv and the second stage of sewerage work was completed under the direction of architect Gorodetsky.

Discussions of this problem and possible options for further construction were raised on the pages of other periodicals of the city - newspapers "Kievlyanin", "Rada", "Posledniye Novosti", "Kiyevskoye Utro" and others provide information on the construction and operation of the Zvirynets pumping station and local sewerage networks serving the Cadet Corps and the Kiev-Pechersk Lavra.

Before the First World War, Lukyanivka, Kurenivka, the entire Pechersk and part of the suburbs were provided with sewerage system, information about which was found on the pages of local periodicals (Levchuk, 2018).

Typhoid, smallpox, diphtheria, tuberculosis, scarlet fever, cholera were typical diseases for Kyiv in the early 20th century, the exacerbation of which was in spring and autumn. At that time, hospitals did not have free beds, because residents of the neighborhood, where there was no qualified medical care, came to Kyiv for treatment. A third of the total number of deaths per year died from these diseases.

During the epidemics, the publications published statistics on the scheme 1) the dead; 2 ) the cured. Thus, on November 8, 1907, the newspaper "Kievskie Vesti" noted: "in 47 days 1242 fell ill with cholera, 363 of whom died and 812 were cured [...] most of the patients were men $197^{\prime \prime 30}$.

In the issues of "Kievlyanin" ${ }^{31}$ for 1898 , there are statistics for the day on typhoid according to the following scheme: 1) arrived 2) recovered; 3 ) "transferred to a shelter for recovering"; 4) the total number of patients who are in city hospitals, among them separately men, women, children.

"Yuzhnaya Kopeyka" contained columns such as "On the spread of infectious diseases", which provided information as follows: "For the period from 25 to 31 March, City Department of Public Health registered the following cases of infectious diseases in Kyiv and its suburbs: abdominal typhoid -3 , saprotyphus -41 , smallpox -10 , diphtheria -10 , scarlet fever -9 , measles -17 , whooping cough -1 , dysentery $-2^{, 32}$.

The newspapers reported on the hospitals to which patients were admitted: the hospital for laborers, the hospital of the Red Cross community, the Jewish hospital, the Alexander and Cyril hospitals, the hospital of the Intercession Monastery and the Lavra hospital. The number of hospitalized and recovered per day was indicated separately for each hospital.

Periodicals allow tracing the borders of the spread of various epidemics. Scarlet fever most often affected residents of Kurenivka, diphtheria - residents of Pecherskyi District, typhus and cholera became the "hallmark" of Lybid and Lukyanovka administrative districts.

The topography of the victims of the epidemics, outlined in Kyiv newspaper periodicals, clearly reflects the social inequality of Kyiv residents: the main hotbeds of infections were working-class districts and suburbs.

In particular, in our opinion, it is worth focusing on the typhus epidemic and the challenges related to it, as its course was covered thoroughly on the pages of Kyiv newspapers. This is confirmed by the following headlines of the newspaper "Kievlyanin": "Donation in favor of typhoid patients", "In the fight against typhoid", "Donation in favor of typhus patients" ${ }^{\prime \prime 3}$. Thus, in the 8th issue of the newspaper "Kievlyanin" for 1898, there is a message "On the premises for recovering from typhoid" with the following content: "Given the approach of the annual contract fairs, etc. Kyiv governor appealed to the mayor with a proposal to vacate 15 the premises of the contract building, which houses a shelter for those recovering from typhoid, by January" ${ }^{\prime 34}$. It was proposed to provide shelter in the Butkevych house, which housed the Kirillov women's almshouse, but the owner of the house refused on the basis of a contract. So, as the correspondent reported, "The question of the premises for this shelter is still open".

Typhoid epidemics burdened the city's health care system, so "Night medical shifts at the Khreshchatyk city hall from $9 \mathrm{pm}$ to $7 \mathrm{am}^{35}$ and "Night medical shifts at

\footnotetext{
${ }^{30}$ Cholera disease spread in Kyiv. Kievskie Vesti. 1907. № 146. November 8. P. 3

${ }^{31}$ Kievlyanin 1898 № 2,4,6,8

32 On the spread of infectious diseases Yuzhnaya Kopeyka. 1912. № 465. April 5.

${ }^{33}$ Kievlyanin 1898 № 4

${ }^{34}$ Kievlyanin 1898 № 8

${ }^{35}$ Kievlyanin 1898 № 3,6,7
} 
Dr. Filipovych's Kyiv-Khreshchatyk pharmacy" ${ }^{36}$ became widespread.

The care of non-typhoid patients was provided by Countess Ignatieva's Hospital, the Mariinsky Community Outpatient Hospital and the Podolsk Red Cross Hospital, as well as the reception of outpatients was conducted by the Alexander Tsesarevich Kyiv City Hospital, as evidenced by the schedules of these medical institutions published in the newspaper "Kievlyanin".

One of the most effective measures in the fight against epidemics was vaccination, there was a smallpox committee in Kyiv, which kept records of children who had not yet contracted smallpox, taught vaccinators and provided them with vaccines and tools.

In 1901, the Kyiv Bacteriological Institute was able to offer consumers: diphtheria and streptococcus anti-sera, tetanus and anthrax anti-sera, as well as Pasteur's vaccine and anti-tuberculosis vaccine ${ }^{37}$. In 1913 there were 25 vaccinators in Kyiv, not only doctors but also barbers.

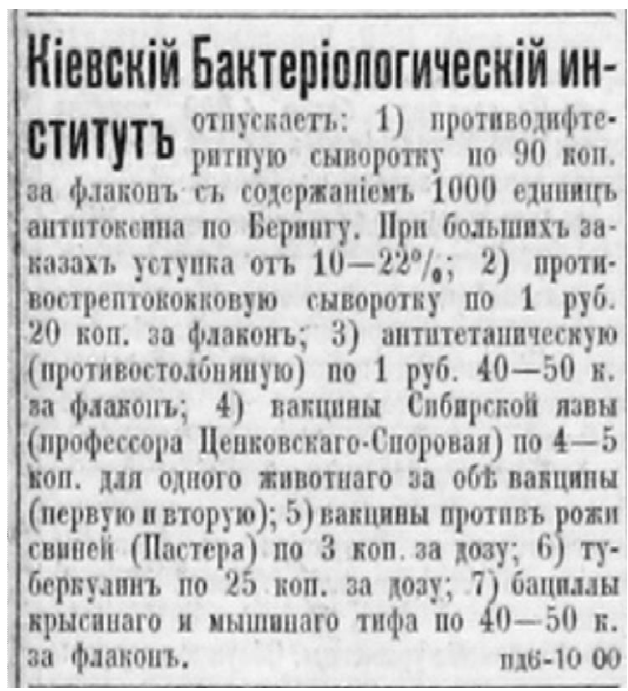

\section{Kiev Bacteriological Institute, Kievlyanin, 1901 № 306}

The fact that the Ukrainian-language brochure "On Cholera" by S. Nos was published in 1875 and 1892 under the auspices of O. Konysky (Boryak, ed., 2013) demonstrates informing about sanitation standards and increasing trust in traditional medicine among the general public.

In 1906, O. Korchak-Chepurkivsky began teaching the course "Fundamentals of Social Hygiene and Public Medicine" at the Kyiv Commercial Institute (Moskalenko et all, 2013).

\section{Conclusions}

Thus, Kyiv periodicals are quite representative in the study of health care, sanitary and epidemiological situation in the city. The processing of newspaper materials has made it possible to identify the problematic areas of work of the city authorities in the sanitary and communal spheres, namely the inconsistency of the municipal economy system with the needs of the time. Newspapers have information on the construction of roads, water supply

\footnotetext{
${ }^{36}$ Kievlyanin 1898 № 2,3,4

${ }^{37}$ Kievlyanin 1901 № 306
}

ISSN 1728-9343 (Print)

ISSN 2411-3093 (Online) and sewerage systems, but this process was slow and did not meet the needs of citizens and utilities. Sewage was discharged into the Dnieper, and the water supply system for extinguishing fires was not adjusted. Newspapers repeatedly stated that waterlines and sewers could protect against the consumption of poor quality water.

The problem of natural dumps, especially in places of social activity such as markets, was unresolvable for the city authorities. Newspaper publications report the sale of overdue products and the existence of natural dumps, despite the tax on cleaning market areas. Concentration of marginalized people (beggars, homeless people, prostitutes) in the markets and illegal alcohol sales did not add attractiveness to trade centers. The issue of building a garbage disposal plant had been repeatedly raised in the newspapers.

The next challenge the city faced was the existence of the Kyiv Prison Castle within its borders. The newspapers reported that the detainees were in unsanitary conditions, were unable to maintain good hygiene and eat normally, and were constantly suffering from bedbugs and rats. This led to the spread of such diseases as diphtheria, smallpox, tuberculosis, scarlet fever.

According to newspapers in Kyiv in the late 19th early 20th century, there was a crisis of the health care system and the instability of the epidemiological situation. During the epidemics, which broke out in spring and autumn, the newspapers published statistical information about patients according to the following scheme: 1) the infected, 2) the dead; 3) the cured.

The content of the newspaper products of that time makes it possible to determine the structures of medical institutions during epidemics, the number of specialists in each of them, to trace the number of hospitalized and recovered in the largest city hospitals (Red Cross Hospital, Jewish Hospital, Alexander and Cyril hospitals, the hospital for laborers, the hospital of the Intercession Monastery and the Lavra hospital).

The topography of the victims of the epidemics, outlined in Kyiv newspaper periodicals, clearly reflects the social inequality of Kyiv residents: the main hotbeds of infections were working-class districts and suburbs.

According to the newspapers of the time, the best counteraction to mass morbidity was vaccination. To this end, the Kyiv Bacteriological Institute produced vaccines against various epidemic diseases, and the smallpox committee registered the vaccinated ones. Ordinary citizens contributed financially to the fight against epidemics by making voluntary contributions.

Newspapers, having entered the practice of everyday life, joined in promoting a healthy lifestyle, publishing reports on special courses on the basics of hygiene in educational institutions.

\section{REFERENCES}

Boryak, H. (ed.) (2013). Ukrayinska identychnist i movne pytannya $v$ Rosiyskiy imperiyi: sproba derzhavnoho rehulyuvannya (1847-1914). Kyiv: Instytut istoriyi Ukrayiny.

Levchuk, O. (2016). Presa Kyyeva 1905 - 1914 rr.: osoblyvosti typolohizatsiyi. In: Dni nauky istorychnoho fakul'tetu (do 150richchya z dnya narodzhennya M.S. Hrushevs'koho). These of conference, Kyiv. (in Ukrainian)

Levchuk, O. (2017). Aktualni problemy sanitarno-epidemichnoho blahopoluchchya miskoho naselennya u vysvitlenni kyyivskykh hazet 1905-1914 rr. (pp. 180-183). Shevchenkivska vesna - 2017: istoriya: Paper thesis. Kyiv (in Ukrainian) 
Levchuk, O. (2018). Hazetna periodyka Kyyeva yak dzherelo doslidzhennya miskoho povsyakdennya (1905-1914 rr.) [Newspaper periodicals of Kyiv as a source of research of city everyday life (1905-1914)] Thesis of the candidate of sciences in social communications, Taras Shevchenko Kyiv National University (in Ukrainian) https://shron1.chtyvo.org.ua/Levchuk Olena/Hazetna periodyka Kyieva iak dzherelo doslidzhennia miskoho povsiakdennia 1905-1914 rr.pdf?

Makarov, A. (2002). Ukrayinskyy pobut Kyyeva pochatku XX st. Z khroniky ukrayinskoho zhyttya Kyyeva 1906-1914 rr.: (za materialamy hazety "Rada"). Khronika-2000, 51-52 [Kyiv Svyata Zemlya]: 251-255. (in Ukrainian)

Moskalenko, V.F., Yavorovskyy, O.P., Stupak, F.Ya., Sakharchuk, I.M. \& Antonyuk, O.Ya. (2012). Akademik O.V.Korchak-Chepurkivs'kyy - fundator sotsial'noyi medytsyny yak nauky ta predmetu vykladannya (do 155-richchya vid dnya narodzhennya). Ukrayina: Zdorovya natsiyi, № 2-3: 13-21 (in Ukrainian)

Musiyachenko, O. (2016). Hazety yak dzherelo doslidzhennya muzychnoho zhyttya Kyyeva kintsya XIX - pochatku XX st. Nauk. pratsi ist. f-tu Zaporiz'koho nats. un-tu, 45(2): 38-41 (in Ukrainian) https://elibrary.kubg.edu.ua/id/eprint/16938/1/O_Musiiachenko NPIFZNU 46 UK.pdf

Senkevych, H. (2010). Miska hazeta: tvorcho-sotsialna paradyhma funktsionuvannya [City newspaper: creative and so- cial paradigm of functioning] Abstract of the dissertation of the candidate of sciences in social communications, Zaporizhia National University (in Ukrainian). https://clck.ru/ZNugi

Vilshanska, O.L. (1995). Zhytlo ukrayinskoyi intelihentsiyi Kyyeva yak vidobrazhennya natsionalnoyi samosvidomosti (pp. 3334). In: Obraz epokhy: kul'turne seredovyshche Kyyeva kintsya XIX - pochatku XX st. Kyiv: Institute of History of the National Academy of Sciences of Ukraine (in Ukrainian)

Vilshanska, O.L. (2011). Povsyakdenne zhyttya mist Ukrayiny naprykintsi XIX na pochatku XX st.: yevropeys'ki vplyvy ta ukrayins'ki natsional'ni osoblyvosti [Everyday life of Ukrainian cities in the late XIX and early XX centuries: European influences and Ukrainian national features] Thesis of the candidate of historical sciences, Institute of History of the National Academy of Sciences of Ukraine (in Ukrainian) http://elib.nakkkim.edu.ua/handle/123456789/2245

Volobuieva, A. M. (2008). Stanovlennya i rozvytok presy Kyyeva (1835-1917): typolohiya, problematyka, natsional'na spryamovanist'. [Formation and development of the Kyiv press (1835-1917): topology, problematic, national orientation]. Abstract of the candidate of sciences in social communications, Taras Shevchenko Kyiv National University (in Ukrainian) https://studwood.ru/719967/zhurnalistika/stanovlennya i roz vitok presi kiyeva 18351917 tipologiya problematika natsionalna spryamovanist

Анна Гедьо,

Київський університет імені Бориса Грінченка (м. Київ, Украӥна)

e-mail: a.hedo@kubg.edu.ua,ORCID0000-0003-4151-0747

Марк Мілютін,

Київський університет імені Бориса Грінченка (м. Київ, Украӥна)

e-mail: mailto:a.hedo@kubg.edu.ua,mymiliutin.iff19@kubg.edu.ua,ORCID 0000-0002-2676-9139

\section{ЕПІДЕМІї В КИЄВІ У ВИСВІТЛЕННІ ГАЗЕТНОї ПЕРІОДИКИ МІСТА кінця XIX- початку XX cm.}

В статті досліджується висвітлення у київських газетах «Киевлянин», «Киевские вести», «Киевская мысль», «Южная копейка» питань санітарно-епідеміологічної ситуації в місті наприкінці XIX - на початку XX ст. Опрацювання матеріалів газет дало змогу: виявити проблемні напрямки роботи міської влади у санітарній та комунальній сферах, а саме неналежний контроль за дотриманням санітарних норм на міських ринках, невирішення проблеми стихійних сміттєзвалищ і безхатченків, незаконного збуту алкоголю, відсутність своєчасного ремонту доріг, спорудження водогону і каналізації. Наведені чинники були основними причинами епідемій тифу, кору, сухоти, віспи, холери. Аналіз статистичних данних наведенних на сторінках періодики, дає змогу відстежити чисельність уражених під час епідемій, встановити типові хвороби для кожного району міста, зумовлені їх географічним розташуванням, контингентом населення, розташувнням таких об'єктів як, в'язниці, базари, кладовища, лікарні.

Ключові слова: газети, Київ, епідемії, хвороби, лікарні, охорона здоров'я.

(C) Anna Hedo, Mark Miliutin

Надійшла до редакції: 08.11.2021

Прийнята до друку: 29.11.2021 